\title{
VERIFICATION OF THE FAÇADE SCAFFOLDING COMPUTER MODEL
}

\author{
P. JAMIŃSKA-GADOMSKA ${ }^{1}$, J. BEC $^{2}$, T. LIPECKI ${ }^{3}$, A. ROBAK $^{4}$
}

\begin{abstract}
This paper presents an analysis of natural vibrations of typical façade scaffolding. Three Finite Element Method models with different levels of accuracy of the real structure of the scaffolding representation were used. Modal analysis was carried out for each of these models. The obtained frequencies and mode shapes were compared with the results from the measurements performed on the full-scale scaffolding. The authors of the paper point out the difficulties arise while modelling such structures, and suggest ways to improve the accuracy of scaffolding computational models.
\end{abstract}

Keywords: façade scaffolding, modal analysis, full-scale measurements, finite element method

\section{INTRODUCTION}

Scaffolding is a temporary structure used during the erection of buildings and bridges as well as during finishing works, maintenance, and repairs. It allows building crew to work at height on a structure. Due to their temporary nature, scaffoldings are often treated in a superficial manner. However, one should keep in mind that scaffolding structures can be of high complexity, and only accurate modelling can aid in avoiding significant errors while performing static and dynamic analyses during the design process.

\footnotetext{
${ }^{1}$ MSc., Eng., Lublin University of Technology, Faculty of Civil Engineering and Architecture, ul. Nadbystrzycka 40, 20-618 Lublin, Poland, e-mail: p.jaminska@pollub.pl

${ }^{2} \mathrm{PhD}$., Eng., Lublin University of Technology, Faculty of Civil Engineering and Architecture, ul. Nadbystrzycka 40, 20-618 Lublin, Poland, e-mail: j.bec@pollub.pl

${ }^{3}$ DSc., PhD., Eng., Lublin University of Technology, Faculty of Civil Engineering and Architecture, ul. Nadbystrzycka 40, 20-618 Lublin, Poland, e-mail: t.lipecki@pollub.pl

${ }^{4}$ MSc., Eng., Lublin University of Technology, Faculty of Civil Engineering and Architecture, ul. Nadbystrzycka 40, 20-618 Lublin, Poland, e-mail: a.robak@pollub.pl
} 
There are few references in literature regarding vibrations of scaffoldings. De Brito [4] have investigated a temporary steel grandstand built with the use of scaffolding elements. He measured vibrations on a real-life structure and on this basis have refined the previously-prepared FEM models [5]. Most papers concerning scaffoldings are listed in Beale's [1] vast review. It presents research from the last 40 years, listing, among others, analyses of modular scaffolding by Pieńko [9], stability analysis by Chan [6] and Liu [8], and work on imperfections and stiffness of joints by Chandrangsu [7]. Papers on façade scaffoldings are less common. More recently Błazik-Borowa published a piece [2] about imperfections in façade scaffoldings and hazardous incidents related to scaffoldings [3]. This paper deals with the natural vibrations of scaffoldings and is based on a single exemplary scaffolding. An in-situ experiment concerning measurements of accelerations was carried out on the full-scale façade scaffolding. Additionally, three Finite Element Method models of different accuracies were created and then used to perform modal analyses. Frequencies and mode shapes obtained from the full-scale measurements and computational analyses were compared in order to verify the utilized FEM models.

\section{DESCRIPTION OF THE ANALYSED SCAFFOLDING}

The subject of the analysis was a façade scaffolding erected next to a new office building located at Mangalia Street in Warsaw (Fig. 1). The scaffolding was mounted using the Altrad-Mostostal PLUS Façade Scaffolding System made of steel prefabricated elements. The main load-bearing element of this system is a closed steel frame. The frame stands are made of pipes. The upper u-section transom welded to the frame enables the installation of steel and aluminium decks. The frame has railing couplings with wedges for the installation of safety railings. Frame rigidity is assured by gusset plates in both upper corners. 


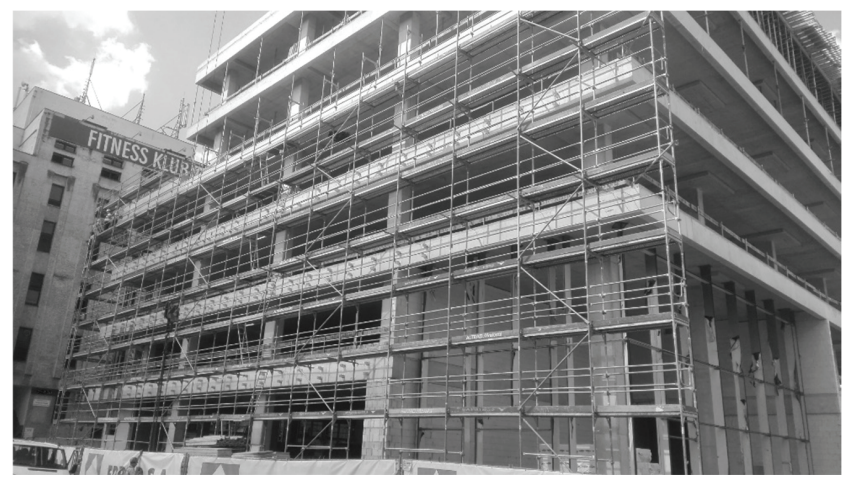

Fig. 1. Analysed full-scale façade scaffolding.

The structure in mind was assembled with use of $0.73 \mathrm{~m}$ wide frames, creating 15 sections in the horizontal direction and 10 in the vertical one. The total length of the scaffolding was $39.08 \mathrm{~m}$, and the maximum height was $18.20 \mathrm{~m}$. The stands of the first level of frames were mounted on base jacks placed on the ground via wooden base plates. The scaffolding was tied down to concrete structural elements of the building with anchor couplings with hooks, in accordance with European regulations [13]. The vertical stiffness of the scaffolding was assured by diagonal braces. There was no mesh clad on the structure during measurements.

\section{IN-SITU MEASUREMENTS}

\subsection{MEASUREMENT SET UP}

The measurements of the full-scale scaffolding were performed to determine the natural frequencies and mode shapes of the structure. A Brüel \& Kjær Pulse 3053-B-12 analyser connected to a laptop and a set of four accelerometers were used to measure accelerations of the scaffolding. The sensors were attached to frameworks below the highest level of decks. Two triaxial piezoelectric accelerometers $4506 \mathrm{~B}-003$ were mounted to the outside gusset plates of frames at both ends of the mentioned deck levels $(1 x y z, 3 x y z)$, whereas two uniaxial accelerometers 4508 were installed at the stand in the middle of the structure (2xy), as shown schematically in Fig. 2. 


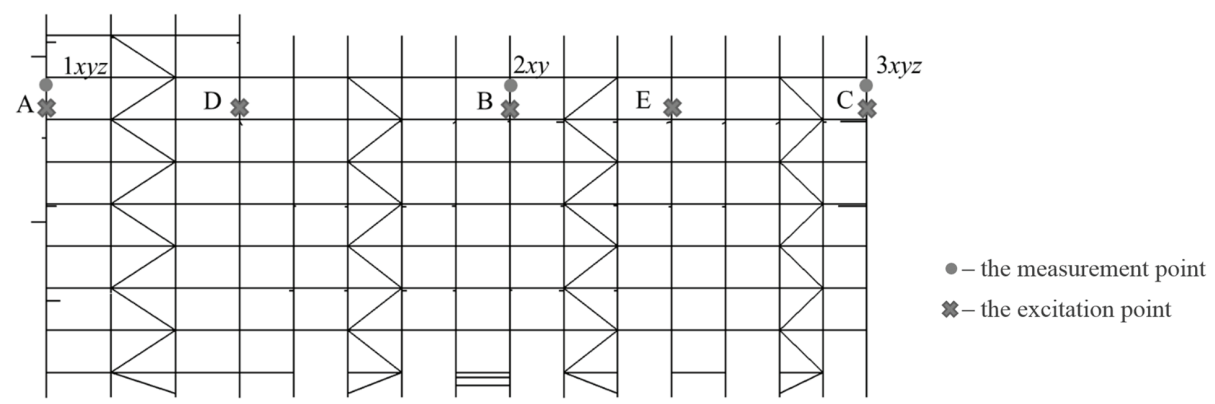

Fig. 2. Scheme of the sensors and excitation point locations.

Triaxial sensors registered accelerations in two horizontal directions: $x$ - along the scaffolding's façade, $y$-perpendicular to the façade, and in the vertical direction $-z$, whereas two uniaxial sensors measured accelerations in both horizontal directions $(x, y)$. The sensors mounted at the scaffolding are presented in Fig. 3.

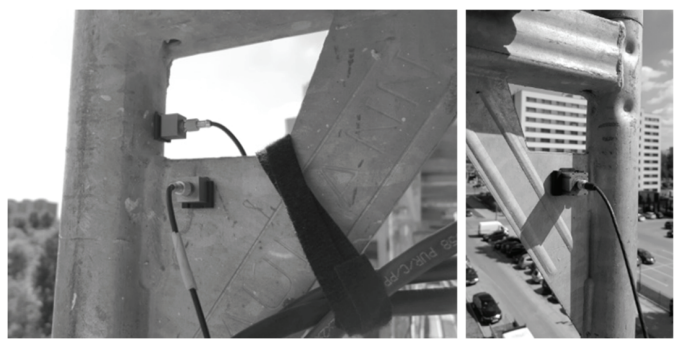

Fig. 3. Uniaxial and triaxial accelerometers mounted on scaffolding frames.

Vibrations were induced by human body motion, such as a person balancing along the scaffolding $(x)$ in the perpendicular direction $(y)$ and rhythmical jumping on framework $(z)$, by a person of a mass approximately equal to $100 \mathrm{~kg}$. Such methods resulted in the excitation of the global mode shapes. There were five excitation points: three in the vicinity of the sensors (A, B, C), and two between them $(\mathrm{D}, \mathrm{E})$, as shown in Fig 2. At each excitation point vibrations were induced in three directions $(x, y$, $z$ ) in the same order, and each measurement was taken twice to make sure that the basic mode shapes were excited. If the basic mode shapes were not excited, the measurement was rejected. A single recording lasted about 20 seconds and included the simultaneous recording of acceleration on eight separate channels. The values of the natural frequencies are similar to the ones obtained during the experiment, i.e. damped vibrations. 


\subsection{ANALYSIS OF IN-SITU MEASUREMENT DATA}

Based on the data gathered from the in-situ measurements, the registered accelerations which were used in frequency analyses were made by using HBM Catman 6.0. In FFT analysis, only the part of the waveform which disappeared after excitation was used. The excited mode shape and the related natural frequency were identified based on the power spectral density function.
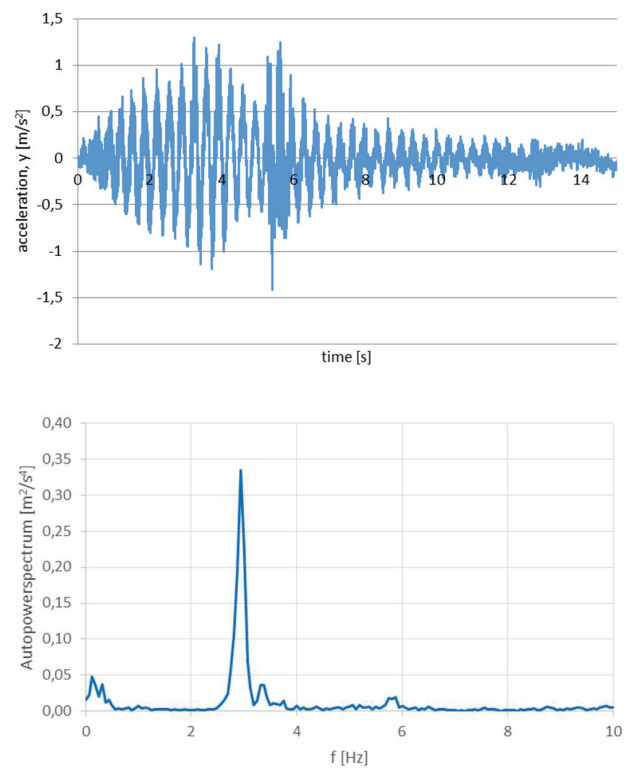

Fig. 4. Acceleration time waveform and its power spectral density (measurement point $2 x y$, excitation point C).

Figure 4 shows the waveform and the power spectral density function of accelerations measured in the middle point of the scaffolding ( $2 x y$ in Fig. 2). In the considered case, vibrations were induced in the $y$ direction at the same level as the measurement point was located, though at the end of the scaffolding (point $\mathrm{C}$ in Fig. 2). Based on the graphs of dominant direction $y$ of global vibrations (from all measurement points and with all excitation positions), it can be said that the scaffolding's induced frequency was equal to $2.94 \mathrm{~Hz}$. This was the most common value, but during all measurements results in the range of $2.75 \mathrm{~Hz}$ to $3.31 \mathrm{~Hz}$ could be identified. 


\section{Finite Element Method Models}

The aim of this study was to create and verify a Finite Element Method (FEM) model which could be used to simulate the behaviour of real scaffoldings with high accuracy. A model which would be used in future analyses should reflect the behaviours of a real structure as closely as possible, and should not consume too much time and computing power.

Three FEM models of different refinement were prepared in Autodesk Simulation Multiphysics 2013. In all three models, general data of material properties and geometrical characteristics of scaffolding elements were taken according to the Altrad-Mostostal catalogues [12]. In the first, preliminary model (M1), a simplified geometry of frames and simplified location of brace ends were assumed. The steel decks were modelled as the truss elements with the respective horizontal stiffness in both directions as in a real deck [10]. The dimensions of the structure were set according to rough in-situ measurements and modular dimensions of scaffolding elements obtained from the producer. The second model (M2) was also made according to modular dimensions, but the frame geometry was the reflection of the real framework, with the correct positioning of the upper u-section and lower transom. Moreover, elements such as gusset plates, railing wedges, and studs welded to the frame were also included as an additional weight in the frame by adjusting its mass density. Positions of brace joints were also improved. Decks were modelled as plate elements with transoms and ledgers with mounting hooks so they could reflect the real decks as close as possible, with low computational effort at the same time [11]. The weight and the stiffness of the decks were also adjusted. The third model (M3) differed from the second only by an introduction of more precise geometry of the whole scaffolding. The dimensions and positioning of all scaffolding elements were set according to geodetic data obtained from the in-situ measurements. The total station was used to measure the position of scaffolding stands (of each stand of frame) in three directions using magnetic surveying points placed $30 \mathrm{~cm}$ below each scaffolding node (vertical connection of stands). Local deflections and damage of stand's pipes were not included in any models.

The distribution of anchors and other supports for all three models was set according to the inventory drawing of the full-scale scaffolding, as shown in Fig 5. 


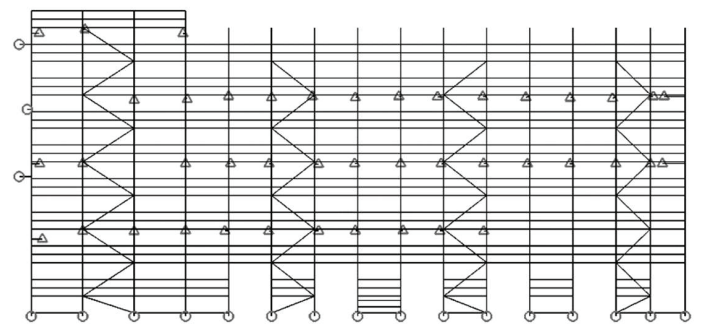

Fig. 5. Distribution of anchors and supports (circles represent supports, triangles - anchors).

In all three models, all elements, except decks, were modelled as beams. In the M2 and M3 models decks were represented by beams and plates, while in the M1 model they were made of truss elements. Connections were set as rigid between every base jack and frame stand, frame stand and frame stand, u-transom and frame stand, anchor coupling with hook and frame stand. Hinges were set between every: angle brace and frame stand, anchor coupling with hook and anchor eye bolt, railing and frame stand, deck hooks and u-transom, toe-boards and frame stand. Clearance in connections between elements was not modelled.

The following boundary conditions were used in the calculations: no translation in $x, y$, and $z$ directions for the simulation of base jacks placed on the base plates, and fixed support at the end of the anchor eye bolt. A 3-D model of the scaffolding is presented in Fig. 6.

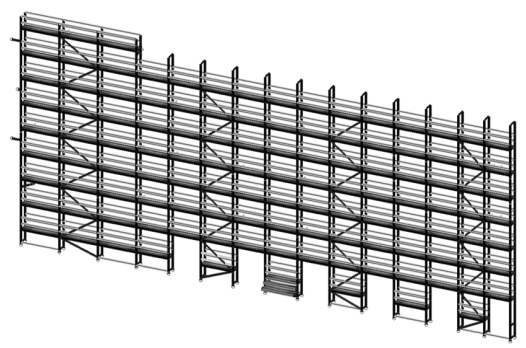

Fig. 6. 3-D model of the scaffolding.

To provide initial verification of the models, static analysis was carried out for each scaffolding model. The models were loaded with the dead-weight only. The obtained maximum displacements were very similar in each of the cases. The differences were very small, not exceeding $3.5 \%$. The data describing in detail the three FEM models is presented in Tab. 1. 
Table 1. Summarized data of FEM model characteristics.

\begin{tabular}{|c|c|c|c|c|c|c|}
\hline \multirow[t]{2}{*}{$\begin{array}{l}\text { FEM } \\
\text { model }\end{array}$} & \multirow[t]{2}{*}{$\begin{array}{c}\text { Model } \\
\text { description }\end{array}$} & \multirow[t]{2}{*}{$\begin{array}{c}\text { Number } \\
\text { of elements }\end{array}$} & \multirow[t]{2}{*}{$\begin{array}{l}\text { Number } \\
\text { of nodes }\end{array}$} & $\begin{array}{c}\text { Volume } \\
\text { of scaffolding }\end{array}$ & $\begin{array}{c}\text { Weight } \\
\text { of scaffolding }\end{array}$ & $\begin{array}{c}\text { Extreme } \\
\text { displacements } \\
\text { (static analysis) }\end{array}$ \\
\hline & & & & {$\left[\mathrm{m}^{3}\right]$} & {$[\mathrm{kN}]$} & {$[\mathrm{mm}]$} \\
\hline M1 & $\begin{array}{c}\text { simplified } \\
\text { geometry of } \\
\text { frames and decks }\end{array}$ & 3904 & 6659 & 2.2558 & 111.89 & 0.696 \\
\hline M2 & $\begin{array}{l}\text { more detailed } \\
\text { geometry of } \\
\text { frames and decks }\end{array}$ & 4754 & 7319 & 2.7752 & 117.43 & 0.672 \\
\hline M3 & $\begin{array}{l}\text { geometry based } \\
\text { on geodetic } \\
\text { measurements }\end{array}$ & 4706 & 7271 & 2.7517 & 117.39 & 0.680 \\
\hline
\end{tabular}

\section{COMPUTATIONAL MODAL ANALYSES}

The mode shapes and the related natural frequencies which were obtained as the result of the modal analysis made with use of Autodesk Simulation Mechanical 2013 Subspace iteration method were used with the Sturm series checking procedure. Most of the mode shapes of the M1 model are of a local character reflecting the anchoring pattern. The third mode shape with natural frequency $f=3.2$ Hz shows global deflection of the highest decks and frames level at the unconstrained part (Tab. 2). Nevertheless, the deflections shown in Table 2 are not in the same phase, they represent the same mode shapes.

Table 2. Modal characteristics of analysed scaffolding models.

\begin{tabular}{|c|c|c|c|}
\hline Mode shape & M1 & M2 & M3 \\
\hline $1^{\mathrm{st}}$ & 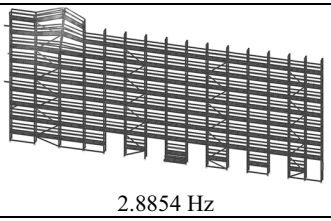 & ${ }_{3.1225 \mathrm{~Hz}}$ & 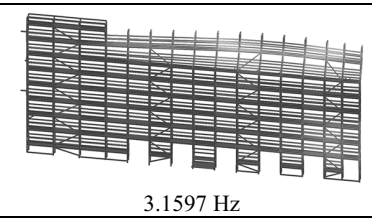 \\
\hline $2^{\text {nd }}$ & 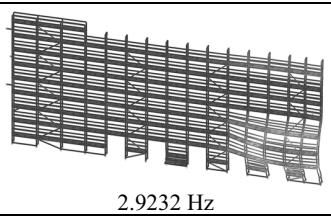 & 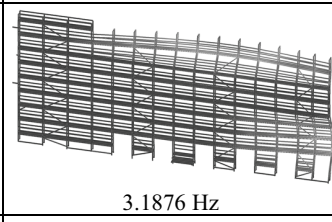 & 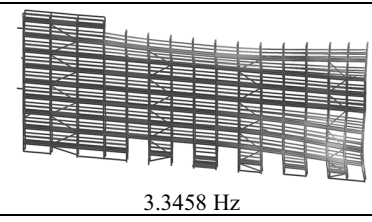 \\
\hline $3^{\text {th }}$ & 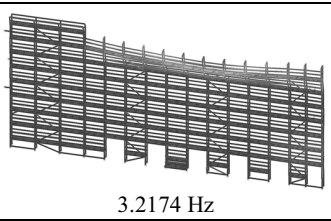 & 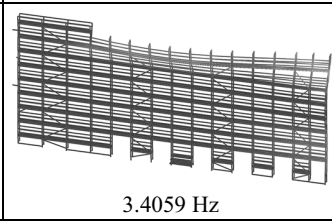 & 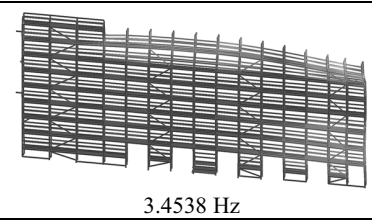 \\
\hline
\end{tabular}




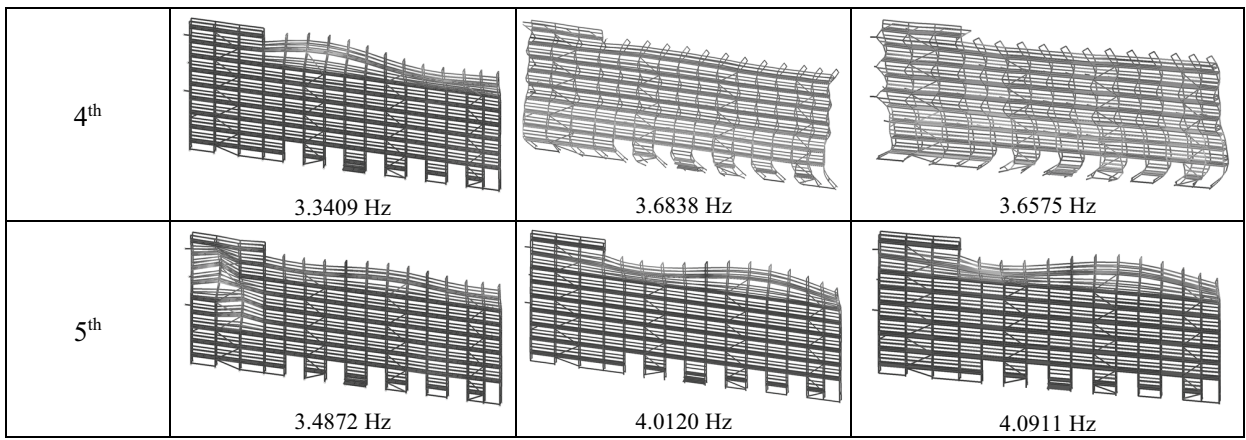

A more detailed geometry of decks and frames (M2 and M3 models) results in a more global response of the structure. The local deflections do not occur individually as in M1, but they can be seen in the $1^{\text {st }}$ and $2^{\text {nd }}$ global mode shapes or they have disappeared completely, due to a higher stiffness of the modelled frames.

An additional introduction of imperfections based on surveying (M3 model) changes the whole picture only slightly, with a small shift in the frequency values.

Taking into account the first five mode shapes, it can be observed that those related to the $f_{3}$ and $f_{4}$ frequencies of the M1 model correspond to the ones for $f_{1}-f_{3}$ frequencies of the M2 and M3 models. The observed modes show out-of-plane bending at the highest level of decks. Moreover, the values are close; $3.2174 \mathrm{~Hz}$ to $3.3409 \mathrm{~Hz}$ (M1), $3.1225 \mathrm{~Hz}$ to $3.4059 \mathrm{~Hz}$ (M2) and $3.1597 \mathrm{~Hz}$ to $3.4538 \mathrm{~Hz}$ (M3).

\section{CONCLusions}

Even though scaffoldings are of a temporary nature it does not mean that they can be neglected in the design process. They can often be structures of high complexity, which makes them quite hard to model.

The accuracy of static analysis of scaffolding structures is usually not at risk, provided careful assembly at the construction site and making sure no discrepancies occur between the physical structure and its project. Many scaffoldings are put together in a chaotic manner, and their geometry often differs from that which was previously designed. For example, ground deformability can have significant impact on scaffold geometry. Uneven subsidence could have a decisive influence on the distribution of forces in the elements of the scaffold.

Careful inventory of the scaffolding with an indication of anchoring points and a detailed description of the state of elements being used, including surveying, allow us to build a computer model of 
scaffolding which closely corresponds to the actual structure. Static analysis of such a structure is usually quite easy, and even the simplest model can adequately reproduce results from a real structure. It can be problematic when it comes to modal analysis and other dynamic analyses. It is particularly difficult to model clearances in the connections between the elements, which cannot be eliminated in a structure of this type, i.e. a temporary scaffold which is repeatedly mounted and dismounted. The structure is assumed to be elastic, though, in fact, due to the clearance in connections, it is not. The lower value of the frequency obtained from in-situ experiments indicates lower stiffness of the scaffolding structure caused, among others, by clearances.

Despite assumption of full elasticity and omitting clearances in connections, a simplified FEM model of the scaffolding was created in accordance with the project, allowing us to carry out modal analysis. The results and their comparison with the in-situ measurements indicate that it is indeed a model allowing for a preliminary assessment of dynamic scaffolding characteristics. Further research, which will be focused on obtaining a better accuracy of the computer model, will require taking into account the issues raised above.

This paper has been prepared as a part of the project supported by the National Centre for Research and Development within the Applied Research Programme (agreement No. PBS3/A2/19/2015 "Modelling of Risk Assessment of Construction Disasters, Accidents, and Dangerous Incidents at Workplaces Using Scaffoldings").

\section{REFERENCES}

1. R. G. Beale, "Scaffold research - A review", Journal of Constructional Steel Research, vol. 98, pp. 188-200, 2014.

2. E. Błazik-Borowa, J. Gontarz, "The influence of the dimension and configuration of geometric imperfections on the static strength of a typical façade scaffolding", Archives of Civil and Mechanical Engineering, vol. 16, no. 3, pp. 269-281, 2016.

3. E. Błazik-Borowa, J. Szer, "The analysis of the stages of scaffolding "life" with regard to the decrease in the hazard at building works", Archives of Civil and Mechanical Engineering, vol. 15, no 2, pp. 516-524, 2015.

4. V. L. de Brito, A. N. Pena, R. L. Pimentel, J. L. V. de Brito, "Modal tests and model updating for vibration analysis of temporary grandstand”, Advances in Structural Engineering, vol. 17, no. 5, pp. 721-734, 2014.

5. V. L. de Brito, R. L. Pimentel, "Finite element models for vibration analysis of temporary grandstands", Proceedings, 8th International Conference on Structural Dynamics EURODYN'2011, Leuven, Belgium, pp. 957-963, 2011.

6. S. L. Chan, Z. H. Zhou, W. F. Chen, J. L. Peng, A. D. Pan, "Stability analysis of semirigid steel scaffolding", Engineering Structures, vol. 17, no. 8, pp. 568-574, 1995.

7. T. Chandrangsu, K. J. R. Rasmussen, "Investigation of geometric imperfections and joint stiffness of support scaffold systems", Journal of Constructional Steel Research, vol. 67, no. 4, pp. 576-584, 2011.

8. H. Liu, Q. Zhao, X. Wang, T. Zhou, D. Wang, J. Liu, Z. Chen, "Experimental and analytical studies on the stability of structural steel tube and coupler scaffolds without X-bracing”, Engineering Structures, vol. 32, no. 4, pp. 1003-1015, 2010. 
9. M. Pieńko, E. Błazik-Borowa, "Numerical analysis of load-bearing capacity of modular scaffolding nodes", Engineering Structures, vol. 48, pp. 1-9, 2013.

10. A. Robak, "Capacity analysis of steel scaffolding decks", Budownictwo i Architektura, vol. 13, no. 2, pp. 357$365,2014$.

11. A. Robak, "The numerical research of the strength of scaffolding boards", Budownictwo i Architektura, vol. 8, no. 1 , pp. 67-81, 2011.

12. Catalogue of Frame Scaffolding Altrad Mostostal, ALTRAD-Mostostal Spółka z o.o.

13. EN 12810-1: Rusztowania elewacyjne z elementów prefabrykowanych - Część 1: Specyfikacje techniczne wyrobów, CEN 2003.

\section{LIST OF FIGURES AND TABLES:}

Fig. 1. Analyzed full-scale façade scaffolding.

Rys. 1. Analizowane rusztowanie fasadowe w skali naturalnej.

Fig. 2. Scheme of the sensors and excitation point locations.

Rys. 2. Schemat rozmieszczenia czujników oraz punktów wzbudzenia drgań.

Fig. 3. Uniaxial and triaxial accelerometers mounted on scaffolding frames.

Rys. 3. Jednoosiowe i trójosiowe akcelerometry zamocowane do ramy rusztowania.

Fig. 4. Acceleration time waveform and its power spectral density.

Rys. 4. Przebieg przyspieszeń i funkcja gęstości widmowej mocy.

Fig. 5. Distribution of anchors and supports.

Rys. 5. Rozmieszczenie zakotwień i punktów podparć.

Fig. 6. 3-D model of the scaffolding.

Rys. 6. Trójwymiarowy model rusztowania.

Tab. 1. Table 1. Summarized data of FEM model characteristics.

Tab. 1. Zestawienie charakterystyk poszczególnych modeli MES.

Tab. 2. Modal characteristics of analysed scaffolding models.

Tab. 2. Charakterystyki modalne analizowanych modeli rusztowania. 


\section{WERYFIKACJA MODELU KOMPUTEROWEGO RUSZTOWANIA FASADOWEGO}

Slowa kluczowe: rusztowanie fasadowe, analiza modalna, badania in-situ, MES

\section{STRESZCZENIE:}

Rusztowania budowlane to konstrukcje tymczasowe wykorzystywane w trakcie wznoszenia obiektów budowlanych, a także podczas prac wykończeniowych. Z uwagi na ich tymczasowy charakter, są one często traktowane w sposób pobieżny. Tymczasem są to konstrukcje złożone, zaś ich niezbyt dokładne modelowanie przyczynia się do istotnych błędów w analizie statycznej i dynamicznej, mogących skutkować potencjalnym stanem awaryjnym konstrukcji rusztowania.

W poniższej pracy przedstawiono analizę komputerową i badania in-situ przykładowego rusztowania fasadowego. W ramach obliczeń przeprowadzono analizy modalne trzech wariantów modelu rusztowania, w wyniku których otrzymano częstości i postaci drgań własnych. Podobne wyniki uzyskane zostały w badaniach in-situ przeprowadzonych na rzeczywistej konstrukcji rusztowania. Wyniki z obu źródeł zostały porównane i na ich podstawie dokonano próby identyfikacji częstości i postaci drgań.

Przedmiotem analiz było rusztowanie fasadowe ustawione przy nowym budynku biurowym zlokalizowanym przy ulicy Mangalia 2 w Warszawie. Rusztowanie zostało wykonane w systemie rusztowań ramowych Mostostal Plus firmy AltradMostostal. Zestawiono je ze stalowych ram o szerokości $0,73 \mathrm{~m}$, tworząc 15 pól w kierunku poziomym i $10 \mathrm{w}$ kierunku pionowym. Całkowita długość rusztowania wynosiła 39,08 m, a wysokość w najwyższej części 18,20 m. Słupki ram za pomocą podstawek i podkładów drewnianych ustawione były na gruncie. Ramy kotwione były do żelbetowych elementów konstrukcyjnych budynku z zachowaniem siatki kotwień zgodnie z odpowiednią normą dotyczącą rusztowań. Analizę modalną konstrukcji przeprowadzono za pomocą systemu Autodesk Simulation Multiphysics 2013, który oparty jest na metodzie elementów skończonych. Wykonano przestrzenny model MES konstrukcji rusztowania składający się z elementów prętowych (M1). Pręty ram fasady zostały zamodelowane jako elementy ramowe, stężenia i bariery - jako elementy kratowe, zaś ażurowe pomosty stalowe przyjęto na podstawie zastępczego modelu złożonego z elementów kratowych. W modelu uwzględniono ciężar krawężników przez zwiększenie masy elementów modelu zastępczego pomostu. Model M1 jest roboczą wersją stworzoną na podstawie zgrubnej inwentaryzacji na miejscu budowy i danych odnośnie wymiarów katalogowych pozyskanych od producenta.

W celu dokładniejszej analizy konstrukcji, stworzono dodatkowe dwa, bardziej szczegółowe modele M2 i M3. W pierwszym z nich, opartym również o wymiary katalogowe, uszczegółowione zostały położenia węzłów, gdzie występują połączenia stężeń i barierek, pomosty zamodelowano za pomocą elementów płytowych, dodano masę dodatkowych elementów poprzez zwiększenie gęstości objętościowej odpowiednich części konstrukcji. W modelu M3 zastosowano wszystkie udoskonalenia wprowadzone w modelu M2, a ponadto przyjęto dokładną geometrię rusztowania, uzyskaną na podstawie pomiarów geodezyjnych przeprowadzonych na placu budowy.

Charakterystyki geometryczne przekrojów poszczególnych elementów rusztowania, a także charakterystyki materiałowe, przyjęto na podstawie katalogów systemowych firmy Altrad-Mostostal.

Na podstawie analizy modalnej konstrukcji zamodelowanej w trzech wariantach uzyskano postaci drgań własnych. Trzecia postać drgań w modelu M1, o częstotliwości $f \approx 3,2 \mathrm{~Hz}$, charakteryzowała się wychyleniem górnego niezakotwionego poziomu ram i pomostów. Większość postaci drgań ma charakter lokalny, co wynika z typowego naprzemiennego wzoru kotwienia rusztowania. Podobnie, przy wykorzystaniu modeli M2 i M3, otrzymano pierwsze 
globalne częstości giętne na zbliżonym poziomie do uzyskanych za pomocą modelu uproszczonego. Lokalne drgania nie stanowią tu oddzielnych postaci drgań, lecz częściowo pojawiają się w postaciach globalnych.

W ramach badań w terenie, dokonano pomiarów drgań swobodnych rusztowania. Wykorzystany został sprzęt Brüel \& Kjær: rejestrator Pulse 3053-B-12 podłączony do komputera przenośnego oraz zestaw trzech akcelerometrów. Czujniki umieszczono poniżej ostatniego poziomu pomostów. Dwa akcelerometry trójosiowe 4506B 003 zostały zamontowane na słupkach skrajnych ram rusztowania, natomiast w środku rusztowania umieszczono dwa czujniki jednoosiowe 4508 . Czujniki trójosiowe zostały ustawione w taki sposób, że mierzone były przyspieszenia drgań w dwóch kierunkach poziomych: $x$ - wzdłuż fasady rusztowania, $y$-w kierunku poprzecznym, a także w kierunku pionowym $-z$. Czujniki jednoosiowe rejestrowały przyspieszenia w kierunkach poziomych $x$ i $y$. Drgania wzbudzane były przez balansowanie ciałem na rusztowaniu lub przez kilka rytmicznych podskoków wykonywanych przez jedną osobę o masie około $100 \mathrm{~kg}$. Drgania wymuszano w pięciu punktach: w trzech w pobliżu zamocowania czujników oraz w dwóch pośrednich. W każdym punkcie wymuszano drgania kolejno w trzech kierunkach $(x, y, z)$, zaś każdy pomiar był powtarzany. Pojedyncza rejestracja trwała około 20 sekund i obejmowała jednoczesny zapis przyspieszeń z ośmiu kanałów.

Otrzymane przebiegi przyspieszeń poddano analizie częstotliwościowej z wykorzystaniem oprogramowania HBM Catman 6.0. Operacji FFT poddano przebiegi drgań po ustaniu wymuszenia. Na podstawie funkcji gęstości widmowej mocy dokonano identyfikacji wzbudzonych częstości drgań własnych. Analizując wykresy funkcji gęstości widmowej mocy uzyskane dla kierunku $y$, przy wymuszeniach w różnych punktach stwierdzono, że wzbudzona częstość drgań w kierunku poprzecznym wynosi 2,94 Hz. Wartość ta jest zbliżona do uzyskanej w analizie modalnej MES.

Rusztowania budowlane, mimo ich tymczasowego charakteru, to konstrukcje bardzo złożone i trudne do modelowania komputerowego. Analiza statyczna konstrukcji nie nastręcza dużych trudności, pod warunkiem starannego montażu i braku rozbieżności między rzeczywiście wzniesioną konstrukcją, a projektem. Wiele rusztowań powstaje w sposób chaotyczny, a ich geometria często odbiega od wcześniej założonej. Istotny wpływ na siły powstające w rusztowaniu ma odkształcalność gruntu. Nierównomierne osiadanie gruntu może mieć decydujący wpływ na rozkład sił w elementach rusztowania.

Szczegółowa inwentaryzacja elementów rusztowania ze wskazaniem punktów kotwienia i dokładnym opisem wykorzystanych elementów oraz z uwzględnieniem pomiarów geodezyjnych, pozwala na budowę modelu komputerowego rusztowania, który w znacznym stopniu odpowiada rzeczywistej konstrukcji.

Problematyczna staje się natomiast analiza modalna i inne analizy dynamiczne. Szczególnie trudne do zamodelowania są luzy występujące w połączeniach między elementami konstrukcji, niemożliwe do wyeliminowania w konstrukcji tego typu. Konstrukcja, która w założeniu jest sprężysta, w rzeczywistości taką nie jest. Pomimo założenia w niniejszej pracy pełnej sprężystości i przy pominięciu luzów w połączeniach, stworzony został uproszczony model MES rusztowania, zgodny z projektem, który pozwolił na przeprowadzenie analizy modalnej. Uzyskane rezultaty i ich porównanie $\mathrm{z}$ wynikami badań wskazują, że jest to model pozwalający na wstępną ocenę charakterystyk dynamicznych. Dalsze prace, które będą miały na celu przybliżenie modelu komputerowego do rzeczywistości, wymagać będą uwzględnienia w analizach powyżej poruszonych problemów. 